BMJ Open

Sport \&

Exercise

Medicine

\section{Sports participation and injury related to the COVID-19 pandemic: will data support observations from clinicians and athletes?}

To cite: Tak I, Rutten J, van Goeverden W, et al. Sports participation and injury related to the COVID-19 pandemic: will data support observations from clinicians and athletes? BMJ Open Sport \& Exercise Medicine 2022;8:e001317. doi:10.1136/ bmjsem-2022-001317

Accepted 23 February 2022
Check for updates

(c) Author(s) (or their employer(s)) 2022. Re-use permitted under CC BY-NC. No commercial re-use. See rights and permissions. Published by BMJ.

${ }^{1}$ Sports Rehabilitation and Manual Therapy, Fysiotherapie Utrecht Oost, Utrecht, The Netherlands

${ }^{2}$ Amsterdam Collaboration on Health \& Safety in Sports (ACHSS), AMC/NUmc IOC Research Center, Amsterdam UMC, Amsterdam, The Netherlands

${ }^{3}$ Department of Health Sciences Amsterdam University of Applied Sciences, Amsterdam, The Netherlands

Correspondence to Dr Igor Tak; igor.tak@gmail.com

\section{THE COVID-19 PANDEMIC AFFECTS SPORTS PARTICIPATION}

The Dutch Sports Participation Index showed a dramatic decrease in sports participation over 2020 and 2021 of up to $15 \%$ per month in the total population aged 5-80 years. ${ }^{1}$ This decrease can be related to closure of sporting grounds and fitness centres, as well as the widespread advice to avoid live human interaction in striving to reduce the spread of coronavirus. Although many started a new type of sport or took part in unorganised physical activities, $22 \%$ were still less active than before the pandemic. ${ }^{1}$ Restricted sports participation is also associated with mental health issues, more in individual than in team sport athletes. ${ }^{2}$

\section{CHANGES IN SPORTS PARTICIPATION AND INJURY}

Up until now, the COVID-19 pandemic (in) directly influenced most athletes, their teams and stakeholders. Athletes intermittently had to withdraw from training or match play, due to positive testing or ongoing changes of governmental regulations. Competitions were interrupted and matches and tournaments were postponed or cancelled. The urge of sport federations to complete competition schedules after lockdown periods conflicts with the need for adequate preparation time. Individual and team performances as well as competition outcomes may have been affected by consecutive changes in training and match play loads, which have put athletes' health at risk. Common concepts of sports participation fluctuation and associations with injury likely apply. After a period of rest between competitive seasons, a new (pre) season start is associated with increased levels of symptoms, injury incidence and burden, ${ }^{3}$ but these usually lower again during the season.

Likely due to team sport restrictions, the numbers of runners increased in The
Netherlands. This as well as novice runners being more prone to injury ${ }^{4}$ are thought to be the main drivers of the reported $40 \%$ increase of running-related injuries in 2020 (1.1 million) compared with 2019 (780 000). ${ }^{5}$ These are mostly overuse injuries, related to the lower extremity in general. Although more troublesome for athletes are the severe acute injuries (ie, from the ankle and knee). These result in longer absence from sports requiring lengthy rehabilitation periods or additional medical treatment. ${ }^{6}$

The 2011 NFL lockout of 20 weeks is a wellknown example of sport cessation of a large group of professional athletes. Consequently, players had unstructured season preparation and a fourfold increase of acute Achilles tendon rupture rates occured during training camp and the season start. ${ }^{7}$ The NFL injury registry showed that the injury numbers in the 2020-2021 season, with incomplete preseason preparation and cancelled practice matches, were higher than in the 3 years before with normal season preparation. ${ }^{8}$ In the German Bundesliga, match-related injury rates increased from 0.27 to 0.84 after the first strict COVID-19-related lockdown period. ${ }^{9}$ How sports participation restrictions relate to sports injury rates during the pandemic remains yet largely unknown.

\section{LOCAL CLINICAL OBSERVATIONS}

We have seen a steady increased influx (2-year moving average) of younger patients $(\leq 45$ years) contacting us after acute knee injury (distortion, rotation trauma, etc, during field based sports) over the past 8 years in our Dutch sports physical therapy clinic. Despite the reduction rates of general sports participation from 2019 to 2020 and 2021, these knee injury numbers still tended to rise during the 2 pandemic years. This could not be related to increased participation rates in 
so-called popular 'high-risk sports' like football and field hockey, as these were contained for a long period or even closed due to COVID-19-related restrictions.

Data from our local orthopaedic surgery department show a $25 \%$ decrease of acute knee injuries and a $30 \%$ overall decrease of ACL surgery in 2021. The Dutch sports injury data registry observed a $30 \%$ reduction of football-related injuries to be presented across all hospital emergency departments in $2020 .^{5}$

At a first glance this may seem contradictory. However, the data were not corrected for exposure time, so true risk injury estimates remain unavailable. General practitioners were holding back from referring these patients and many injured athletes have probably avoided going, to an emergency department or orthopaedic surgery setting, as media repeatedly reported hospitals to be overcrowded by patients with COVID-19. Hospital capacity available resulted in lower elective care volume; thus, we may be looking at a delay in care with a rise in the year(s) to come. Lower medical specialist visits and increased primary healthcare may indicate a shift of those seeking care, but data are not yet available to support this confidently.

\section{BEYOND THE NUMBERS}

During our clinical patient contacts, we noted that many injured athletes, with acute knee injury, attributed this, at least partially, to irregular training loads, being less prepared while restarting full training and, when allowed, (practice) match play. Decreased strength and fitness were commonly suggested factors as well as lower participation rates of sport specific training. They often noted a loss of performance in their specific context and expressed this in terms such as 'increased clumsiness', 'slower and impaired actions and reactions' and 'making more faults in decision making on the pitch'. This is likely related to longer training periods without physical contact, lacking the physical demands that keep individuals adequately prepared during contact sports.

\section{PUTTING THE PUZZLE}

The COVID-19 pandemic seems to be a relevant factor with unknown magnitude acting in the complex interplay of sports, injury and performance. Injury databases can be used for analysing this interplay, but injury numbers need to be interpreted with caution due to many changes in exposure and type of sport specific loading.

Calculating injury risk estimates and defining risk profiles regarding types of training and playing load will give more insight. This will require a huge effort as exposure times have been affected largely by temporary sporting restrictions and were different between types of sport, competition (indoor/outdoor) or countries. Next to these quantitative analyses, qualitative explorations of how athletes themselves experienced the relation between irregular sports participation on their performance or injury will provide additional relevant information. Clinicians play an important role in asking these questions assisting in pattern recognition. This will guide collecting qualitative data that can be of help in optimising decision-making on how to deal with a comparable situation in the future.

\section{Twitter Igor Tak @igorjitak}

Contributors All authors have contributed to the drafting of the article, agree with its message and approved the final version to be submitted.

Funding The authors have not declared a specific grant for this research from any funding agency in the public, commercial or not-for-profit sectors.

Competing interests None declared.

Patient consent for publication Not applicable.

Ethics approval This study does not involve human participants.

Provenance and peer review Not commissioned; externally peer reviewed.

Open access This is an open access article distributed in accordance with the Creative Commons Attribution Non Commercial (CC BY-NC 4.0) license, which permits others to distribute, remix, adapt, build upon this work non-commercially, and license their derivative works on different terms, provided the original work is properly cited, appropriate credit is given, any changes made indicated, and the use is non-commercial. See: http://creativecommons.org/licenses/by-nc/4.0/.

\section{ORCID iD}

Igor Tak http://orcid.org/0000-0002-2980-1325

\section{REFERENCES}

1 Klein de K, Dijkhuis T, Ros M. Deze impact heeft corona op Het beweeggedrag in Nederland; Alles over sport, 2021. Available: https:// www.allesoversport.nl/thema/gezonde-leefstij//deze-impact-heeftcorona-op-het-beweeggedrag-in-nederland/

2 Guddal MH, Stensland Synne Øien, Småstuen MC, et al. Physical activity and sport participation among adolescents: associations with mental health in different age groups. results from the Young-HUNT study: a cross-sectional survey. BMJ Open 2019;9:e028555-10.

3 Stokes KA, Jones B, Bennett M, et al. Returning to play after prolonged training restrictions in professional collision sports. Int $J$ Sports Med 2020;41:895-911.

4 Kemler E, Blokland D, Backx F, et al. Differences in injury risk and characteristics of injuries between novice and experienced runners over a 4-year period. Phys Sportsmed 2018;46:485-91.

5 VeiligheidNL Sportblessures in Nederland - cijfers 2020; Amsterdam, 2020. Available: https://www.veiligheid.nl/.ibmmodres/domino/ OpenAttachment/veiligheid/website.nsf/FD55DBE4F79F1E11C125 87AA00541029/asset/Cijferrapportage sportblessures 2020.pdf.

6 Bahr R, Clarsen B, Ekstrand J. Why we should focus on the burden of injuries and illnesses, not just their incidence. Br J Sports Med 2018;52:1018-21.

7 Myer GD, Faigenbaum AD, Cherny CE, et al. Did the NFL lockout expose the Achilles heel of competitive sports? J Orthop Sports Phys Ther 2011;41:702-5.

8 Baker HP, Pirkle S, Cahill M, et al. The injury rate in national football League players increased following cancellation of Preseason games because of COVID-19. Arthrosc Sports Med Rehabil 2021;3:e1147-54.

9 Seshadri DR, Thom ML, Harlow ER, et al. Case report: return to sport following the COVID-19 Lockdown and its impact on injury rates in the German soccer League. Front Sports Act Living 2021;3:1-7. 